\title{
Zjawisko terroryzmu a bezpieczeństwo narodowe Rzeczypospolitej Polskiej
}

\author{
The phenomenon of terrorism and national security \\ of the Republic of Poland
}

\begin{abstract}
Streszczenie:
Autorka w artykule omawia problematykę obejmującą zagadnienie terroryzmu, odwołując się zarówno do analizy tego pojęcia, jak i zachowań z tym związanych. Jej celem jest przede wszystkim analiza możliwego zagrożenia terrorystycznego i przegląd najważniejszych zagrożeń jakie w związku z tym pojawiają się w dokumentach Strategii Bezpieczeństwa Narodowego RP oraz Białej Księdze Bezpieczeństwa Narodowego RP. Autorka podejmuje również próbę odpowiedzi na pytanie czy Polska jest wolna od tego typu zagrożeń.
\end{abstract}

Słowa kluczowe: terroryzm, terrorysta, zagrożenie, Strategia Bezpieczeństwa Narodowego RP, Biała Księga Bezpieczeństwa Narodowego RP

\begin{abstract}
:
The author discusses the issue of terrorism in the article, referring to both the analysis of this concept and related behaviors. Its aim is, first of all, to analyze the possible terrorist threat and review the most important threats that appear in the documents of the National Security Strategy of the Republic of Poland and the White Book of National Security of the Republic of Poland. The author also attempts to answer the question whether Poland is free from this type of threats.
\end{abstract}

Keywords: terrorism, terrorist, threat, National Security Strategy of the Republic of Poland, White Book of National Security of the Republic of Poland 
Weronika Baran - Zjawisko terroryzmu a bezpieczeństwo...

\section{Wprowadzenie - zjawisko terroryzmu}

Zastanawiając się nad zjawiskiem terroryzmu w kontekście bezpieczeństwa narodowego Rzeczypospolitej Polskiej, należy postawić pytanie, czym w istocie jest terroryzm. Mimo tak dużej ilości wyjaśnień, wciąż poszukiwana jest jego właściwa definicja, gdyż precyzyjne określenie tego pojęcia napotyka na liczne trudności.

W literaturze przedmiotu podkreśla się, że wynika to przede wszystkim z jego specyfiki, gdyż określenie „terrorysta” zostaje nadane przez świat zewnętrzny - głównie przez rządy zaatakowanych państw. Można oczywiście odwoływać się do kryteriów obiektywnych, wskazujących, że jest to osoba, która popełnia przestępstwo o charakterze terrorystycznym ${ }^{1}$, jednak wyczerpujące wymienienie cech charakteryzujących samego sprawcę wydaje się trudne chociażby ze względu na różne motywy przyświecające osobom dopuszczających się takich działań. Niejednokrotnie określenie to jest stosowane do podmiotów dopuszczających się ataku z użyciem przemocy. Terroryzm jest określany jako „zamierzona przemoc lub groźba jej użycia celem zastraszenia rządów lub społeczeństw” bądź „użycie lub groźba użycia przemocy przeciwko osobie lub własności, aby doprowadzić do działania o charakterze politycznym, religijnym lub ideologicznym"2.

Stosunkowo łatwo jednak zauważyć, że przedstawione definicje nie są precyzyjne. Samo pojęcie przemocy jest bardzo szerokie, a tym samym wszelkie próby definiowania terroryzmu nie oddają $\mathrm{w}$ pełni

\footnotetext{
1 Zgodnie z Ustawą z dnia 6 czerwca 1997 r. - Kodeks karny, tj. Dz. U. 2018, poz. 1600 ze zm.: Przestępstwem o charakterze terrorystycznym jest czyn zabroniony zagrożony kara pozbawienia wolności, której górna granica wynosi co najmniej 5 lat, popełniony $w$ celu:

1) poważnego zastraszenia wielu osób,

2) zmuszenia organu władzy publicznej Rzeczypospolitej Polskiej lub innego państwa albo organu organizacji międzynarodowej do podjęcia lub zaniechania określonych czynności,

3) wywołania poważnych zakłóceń w ustroju lub gospodarce Rzeczypospolitej Polskiej, innego państwa lub organizacji międzynarodowej - a także groźba popetnienia takiego czynu. (art. $115 \S 20$ k.k.).

2 C. Townshend, Terroryzm, Łódź 2017, s. 21-22.
} 
istoty tego zjawiska. Ataki terrorystyczne cechują się nieprzewidywalnością (bowiem są dokonywane w sposób nagły i nieoczekiwany). Ze względu na tak szeroki zakres pojęciowy terminu „terrorysta” nie jest możliwe ograniczenie definicji wyłącznie do wskazania konkretnego podmiotu o właściwych mu cechach.

W toku dyskusji nad koniecznością przeciwdziałania terroryzmowi można spotkać się ze stwierdzeniem, iż mamy do czynienia z „wojną z terroryzmem". Sposób prowadzenia działań przez terrorystów uniemożliwia jednak podjęcie środków w celach obronnych, zatem takich działań nie należy odnosić do międzynarodowego prawa wojennego. Podkreśla się również, że terroryzm jako zjawisko nie jest na tyle silny i zorganizowany, by wypowiedzieć wojnę, tak jak ma to miejsce w przypadku państw, które toczą ze sobą wojny (działania terrorystów są często przypadkowe - skierowane do przypadkowych celów np. grupy ludzi w miejscu publicznym) ${ }^{3}$.

Co istotne, zgodnie z art. 1 III Konwencji haskiej z $1907 \mathrm{r}^{4}$ formalny akt wypowiedzenia wojny przez państwa poprzedza ewentualne rozpoczęcie działań zbrojnych. Dodatkowo konieczne jest określenie żądań i wyznaczenie stosownego terminu na ich realizację, natomiast ich niewypełnienie implikuje stan wojny5. Jak wynika z przedmiotowej regulacji prawnej, która dotyczy „rozpoczęcia kroków nieprzyjacielskich", to państwa są podmiotem wypowiadającym wojnę. Działania terrorystyczne najczęściej podejmowane są przez organizacje, które nie mają do tego formalnej legitymacji, zatem dokonywane przez nie ataki, jak już wcześniej zostało wskazane, nie powinny być odnoszone do międzynarodowego prawa wojennego.

Trzeba zauważyć, że w przypadku osób, które dopuszczają się zamachów terrorystycznych, co do zasady nie mamy do czynienia z za-

\footnotetext{
3 Tamże, s. 25-26.

${ }^{4}$ Konwencja dotycząca rozpoczęcia kroków nieprzyjacielskich (III konwencja haska), Haga, 18 października 1907 r. (Dz. U. 1927, Nr 21, poz. 159).

5 Zob.: P. Ochmann, J. Wojas, Współczesne znaczenie aktu wypowiedzenia wojny uwagi w kontekście konfliktu na wschodzie Ukrainy, „Bezpieczeństwo. Teoria i praktyka" 2015, nr 3, s. 83-84.
} 
Weronika Baran - Zjawisko terroryzmu a bezpieczeństwo...

burzeniami osobowości ich sprawców. Uważa się, że „odpowiednia sytuacja społeczna, przekonanie o słuszności własnej racji oraz dehumanizacja ofiar jest w stanie przekształcić normalnego człowieka w terrorystę"6. Osoby, które dokonują zamachów terrorystycznych, mają pewne wspólne cechy (wskazuje się najczęściej na działanie w imię określonej idei, ukierunkowanie na skonkretyzowany cel, agresja, egocentryzm, bezrefleksyjność, zdeterminowanie, bezwzględność ${ }^{7}$ ). Dodatkowo można w ich przypadku zaobserwować przekonanie o zasadności ich własnej ideologii oraz swoistą racjonalizację podejmowanych przez nich działań8.

0 terroryzmie niekiedy mówi się jako o tzw. „systemie naczyń połączonych", obejmującym pewne elementy składowe jak również powiązania między tymi elementami cechujące się występowaniem zróżnicowanych przyczyn i motywów działania sprawców ${ }^{9}$. Dla przykładu warto wskazać na tzw. „rodzimy terroryzm”, który obejmuje akt przemocy na podłożu religijnym, ideologicznym bądź politycznym ukierunkowany na państwa zachodnie, dokonywany przez osoby związane $\mathrm{z}$ tym miejscem ${ }^{10}$.

Zamiar wywierania wpływu jest głównym celem terrorystów. Przez wymuszanie określonego działania bądź zaniechania na rządach, organizacjach lub grupach społecznych terroryści wzbudzają lęki i obawy w danym społeczeństwie przed ewentualnym zamachem. Element strachu połączony z użyciem przemocy stanowi istotę terroryzmu, gdyż za pomocą tych instrumentów terroryści próbują przejąć kontrolę i zdobyć dominację. Nie są istotne środki, za pomocą których

\footnotetext{
${ }^{6}$ A. Biela, D. Bryk, G. Kida, M. Wołońciej, Psychologiczne uwarunkowania terroryzmu jako zjawiska globalnego, [w:] P. Jaroszyński et al. (red.), Terroryzm - dawniej i dziś, Lublin 2010, s. 252.

7 T. Kubik, M. Kossowska, Reprezentacje poznawcze terrorysty i ich indywidualne uwarunkowania, „Psychologia Społeczna” 2007, tom 2, nr 02 (04), s. 137.

8 Ibidem, s. 254.

${ }^{9}$ S. Wojciechowski, Terroryzm na poczatku XXI wieku. Pojęcie, istota i przyczyny zjawiska, Poznań 2011, s. 117.

${ }_{10}$ M. Adamczuk, Rodzimy terroryzm jako zjawisko zagrażające bezpieczeństwu w Europie, „Bezpieczeństwo narodowe. Pozamilitarne aspekty bezpieczeństwa” 2011, nr I, s. 17.
} 
osiągają oni swoje cele. Osoby, które dokonują zamachów terrorystycznych, nie zważają na skutki podejmowanych przez siebie działań. Podkreśla się, że wybór ofiar często nie jest przypadkowy, gdyż przede wszystkim ma na celu wywołanie wstrząsu u osób, które są obserwatorami ataku. Czynnikiem, który wydaje się najbardziej istotny w kwestii wyboru celu zamachu, są jego konsekwencje medialnopropagandowe ${ }^{11 .}$

W zależności od sytuacji, jaka ma miejsce w konkretnym państwie, możemy mówić o czynnikach wewnętrznych wpływających na intensywność, częstotliwość bądź siłę omawianego zjawiska ${ }^{12}$. Warto wskazać, że „efektywność terroryzmu uzależniona jest od umiejętności wykorzystywania mechanizmów psychologicznych, pozwalających uzyskiwać pożądane zmiany w postawach i zachowaniach w wyniku zniekształceń percepcji i kształtowania afektów namierzonych widowni. Strach, lęk i manipulacja percepcją ryzyka to krytyczne elementy strategii terrorystycznej" 13 .

W XXI wieku zdecydowanie zwiększyła się częstotliwość używania terminu „terroryzm”, czego przyczyną były m. in. zamachy, które miały miejsce 11 września 2001 roku. Wielość i różnorodność definicji tego pojęcia wskazuje zaś na jego złożony charakter, na który mają wpływ uwarunkowania religijne i narodowościowe, ale również polityczne, ekonomiczne, społeczne czy kulturowe stanowiące elementy tożsamości zbiorowej. W odniesieniu do społeczności tożsamość oznacza „Świadomość wspólnych cech i poczucie jedności”14. Niewątpliwie stanowią one pewien wspólny mianownik dla tego zjawiska, bowiem niejednokrotnie stają się przyczyną aktów noszących znamiona terroru.

${ }^{11}$ A. Nowakowska-Krystman, W. Zubrzycki, P. Daniluk, E. Mazur-Cieślik, Terroryzm w ujęciu strategicznym, Warszawa 2015, s. 76-77.

12 S. Wojciechowski, Terroryzm na poczq̨tku XXI wieku. Pojęcie przejawy przyczyny, Poznań 2013, s. 22-24.

13 B. Bolechów, Terroryzm aktorzy, statyści, widownie, Warszawa 2010, s. 250.

14 Słownik języka polskiego - hasło tożsamość, https://sjp.pwn.pl/szukaj/to\%C 5\%BCsamo\%C5\%9B\%C4\%87.html [dostęp: 30.03.2019 r.]. 
Weronika Baran - Zjawisko terroryzmu a bezpieczeństwo...

\section{Terroryzm w Strategii Bezpieczeństwa Narodowego Rzeczypospolitej Polskiej}

Konieczność bliższego wyjaśnienia problematyki bezpieczeństwa narodowego Rzeczypospolitej Polskiej w kontekście zagrożeń terrorystycznych czyni zasadnym odwołanie się do dokumentu, jakim jest Strategia Bezpieczeństwa Narodowego Rzeczypospolitej Polskiej zatwierdzona w dniu 5 listopada 2014 roku przez Prezydenta Rzeczypospolitej Polskiej Bronisława Komorowskiego. Jest to dokument dotyczący bezpieczeństwa państwa, wydawany na podstawie ustawy z dnia 21 listopada 1967 r. o powszechnym obowiązku obrony Rzeczypospolitej Polskiej15. W art. 4a ustawy, który stanowi o kompetencjach Prezydenta RP, ustawodawca wskazuje, że Prezydent stojący na straży suwerenności i bezpieczeństwa państwa, nienaruszalności i niepodzielności jego terytorium zatwierdza między innymi strategię bezpieczeństwa narodowego na wniosek Prezesa Rady Ministrów, jak również wydaje $\mathrm{w}$ drodze postanowienia dokumenty wykonawcze do strategii. Jednym z zadań Rady Ministrów „wykonywanych w ramach zapewniania zewnętrznego bezpieczeństwa państwa i sprawowania ogólnego kierownictwa w dziedzinie obronności kraju" jest opracowywanie projektów strategii bezpieczeństwa narodowego ${ }^{16}$.

$\mathrm{W}$ omawianym dokumencie $\mathrm{w}$ poszczególnych rozdziałach zostały poruszone następujące kwestie: Polska jako podmiot bezpieczeństwa, środowisko bezpieczeństwa Polski, koncepcja działań strategicznych strategia operacyjna, jak również koncepcja przygotowań strategicznych - strategia preparacyjna. Zasadnicza różnica pomiędzy strategią operacyjną a strategią preparacyjną sprowadza się do tego, że pierwsza $\mathrm{z}$ nich określa priorytety polityki bezpieczeństwa, natomiast druga koncentruje się na przygotowaniach strategicznych, mając na względzie odpowiednie połączenie czynników wewnętrznych oraz

\footnotetext{
15 Ustawa z dnia 21 listopada 1967 r. o powszechnym obowiązku obrony Rzeczypospolitej Polskiej (tekst jedn. Dz. U. 2017, poz. 1430 ze zm.).

16 Zob. art. 6 ust. 1 pkt. 1 ustawy o powszechnym obowiązku obrony Rzeczypospolitej Polskiej.
} 
zewnętrznych, a także militarnych i pozamilitarnych w systemie bezpieczeństwa narodowego ${ }^{17}$.

Problematyka zjawiska terroryzmu w Strategii Bezpieczeństwa Narodowego Rzeczypospolitej Polskiej pojawia się kilkukrotnie w różnym kontekście (m. in. jako wskazanie kluczowego zagrożenia dla bezpieczeństwa globalnego, ale także dla Polski, z uwagi na jego międzynarodowy charakter). Warto zauważyć, że jako istotny punkt w zwalczaniu i przeciwdziałaniu terroryzmowi, a także proliferacji broni masowego rażenia wskazano udoskonalenie rozwiązań systemowych jako cel strategiczny w dziedzinie bezpieczeństwa. Dodatkowo podczas omawiania środowiska bezpieczeństwa Polski w wymiarze globalnym ustosunkowano się do „podważenia wiarygodności porozumień rozbrojeniowych, $\mathrm{w}$ tym dotyczących nieproliferacji broni masowego rażenia" jako poważnego zagrożenia dla ewentualnego dostępu do takiej broni przez ugrupowania terrorystyczne. Międzynarodowy terroryzm oraz przestępczość zorganizowana w kontekście omawianych zagrożeń dla bezpieczeństwa globalnego stanowią elementy, które powodują konflikty wewnętrzne, niestabilność oraz patologie takie, jak np. handel ludźmi ${ }^{18}$. Podkreśla się, że rozwój nowych technologii teleinformatycznych oraz sieci Internet wiąże się z występowaniem nowych zagrożeń, takich jak między innymi cyberterroryzm (rozumiany jako atak przy wykorzystaniu systemu informatycz-

\footnotetext{
17 Strategia bezpieczeństwa narodowego - Prof. Tomasz Aleksandrowicz, https://wszystkoconajwazniejsze.pl/tomasz-aleksandrowicz-strategia-bezpieczenst wa-narodowego-rp/ [dostęp: 30-0-2019 r.].

18 Zgodnie z art. $115 \S 22$ Kodeksu karnego: Handlem ludźmi jest werbowanie, transport, dostarczanie, przekazywanie, przechowywanie lub przyjmowanie osoby z zastosowaniem:

1) przemocy lub groźby bezprawnej,

2) uprowadzenia,

3) podstępu,

4) wprowadzenia $w$ błąd albo wyzyskania błędu lub niezdolności do należytego pojmowania przedsiębranego działania

5) nadużycia stosunku zależności, wykorzystania krytycznego położenia lub stanu bezradności,

6) udzielenia albo przyjęcia korzyści majątkowej lub osobistej albo jej obietnicy osobie sprawującej opiekę lub nadzór nad innq osobq.
} 
Weronika Baran - Zjawisko terroryzmu a bezpieczeństwo...

nego bądź urządzenia elektronicznego cechujący się stosowaniem przemocy dla osiągnięcia określonego celu ${ }^{19}$ ). W kontekście środowiska bezpieczeństwa Polski w wymiarze globalnym zwrócono również uwagę na ekstremizm jako ważne zagrożenie dla bezpieczeństwa międzynarodowego, który może mieć między innymi podłoże etniczne czy religijne. Niebezpieczeństwo przejawia się w tym miejscu przede wszystkim w wykorzystaniu terroryzmu jako instrumentu działania20.

Uzupełniająco należy zaznaczyć, iż: „Niekontekstualna definicja ekstremizmu, tzn. taka, która jest niezależna od otoczenia aktywności ruchu (ekstremizm jest bowiem interpretowany inaczej w państwach demokratycznych i niedemokratycznych), winna uwzględniać fakt, że ekstremiści opowiadają się nie tylko przeciwko demokratycznemu porządkowi wartości, ale i nie wyrzekają się stosowania przemocy, a realną bądź wyobrażoną zbiorowość traktują jako nadrzędną nad jednostkami"21. Przykładem takich działań są np. ruchy anarchistyczne oraz narodowe połączone $\mathrm{z}$ grupami subkulturowymi o pochodzeniu chuligańskim²2.

Mając na względzie przytoczoną na wstępie definicję terroryzmu (do której konstytutywnych elementów należy przemoc oraz groźba i użycie ich dla określonego celu), należy zauważyć, iż wykazuje ona pewne cechy wspólne z ekstremizmem oraz handlem ludźmi. Wszystkie te zjawiska łączy bowiem przemoc i chęć osiągnięcia określonego celu, które co do zasady odbywają się przy naruszeniu obowiązującego prawa.

Odwołując się do środowiska bezpieczeństwa Polski w wymiarze krajowym, zauważono, że „międzynarodowy charakter terroryzmu

19 Zob. T. Szubrycht, Cyberrterroryzm jako nowa forma zagrożenia terrorystycznego, „Zeszyty Naukowe Akademii Marynarki Wojennej” 2005, nr 1 (160), s. 174-176.

${ }^{20}$ Szerzej na ten temat zob. Strategia Bezpieczeństwa Narodowego Rzeczypospolitej Polskiej, s. 17-19, Warszawa 2014, https://www.bbn.gov.pl/ftp/SBN\%20RP.pdf [dostęp: 1-02-2018].

21 P. Malendowicz, Ekstremizm polityczny a bezpieczeństwo państwa i ład międzynarodowy, „Bezpieczeństwo Narodowe” 2015, nr 1, s. 153.

22 Strategia Bezpieczeństwa Narodowego..., s. 17-19. 
oraz intensywność jego przejawów sprawiają, że Polska nie jest wolna od tego typu zagrożeń. Szczególnie niebezpieczne mogą okazać się pojedyncze osoby lub małe grupy osób wykorzystujące metody terroru jako narzędzia do realizowania własnych celów o podłożu politycznym, społecznym, ekonomicznym lub religijnym"23.

Osobną kwestią jest problematyka przeciwdziałania i zwalczania terroryzmu i ekstremizmu, gdyż jak zostało wskazane w Strategii Bezpieczeństwa Narodowego RP, stanowi to wyzwanie ze względu na skalę i zasięg zjawiska terroryzmu większości organów międzynarodowych i państwowych. „Do najważniejszych zadań w zakresie przeciwdziałania i zwalczania terroryzmu i ekstremizmu należą: rozpoznawanie i monitorowanie zagrożeń terrorystycznych dla Polski i jej obywateli w kraju i za granicą; wykrywanie i neutralizacja zagrożeń terrorystycznych, w tym fizyczne zwalczanie terroryzmu; eliminowanie źródeł finansowania terroryzmu; ściganie karne sprawców zagrożeń terrorystycznych, zgodnie z prawem krajowym oraz obowiązującymi Polskę normami prawa międzynarodowego; rozpoznawanie źródeł terroryzmu i symptomów radykalizacji zachowań i zapobieganie im; współpraca międzynarodowa dwu- i wielostronna na szczeblu politycznym, operacyjnym, analitycznym i prawno-karnym w obszarze zwalczania terroryzmu; profilaktyka antyterrorystyczna, rozwój partnerstwa publiczno-prywatnego, polityka medialna i informowanie społeczeństwa o potencjalnych zagrożeniach, edukacja społeczna". Dodatkowo istotną rolę odgrywa ochrona polskich przedstawicielstw i placówek w miejscach, które cechują się wysokim poziomem zagrożenia terroryzmem bądź w których występują napięcia społeczne ${ }^{24}$.

Terroryzm jest niewątpliwie zjawiskiem, którego nie należy lekceważyć. Ministerstwo Spraw Zagranicznych zaznacza, że nie jest możliwa zupełna eliminacja zagrożenia atakiem terrorystycznym, jednak co jest niezwykle istotne - należy podejmować działania, które stwa-

\footnotetext{
23 Ibidem, s. 25.

24 Zob. Strategia Bezpieczeństwa Narodowego..., s. 34-37.
} 
Weronika Baran - Zjawisko terroryzmu a bezpieczeństwo...

rzają szansę na jego uniknięcie. Ministerstwo Spraw Zagranicznych wskazało na następujące aktywności:

1) zwracanie uwagi na ewentualne ostrzeżenia skierowane do podróżujących;

2) zapoznawanie się z informacjami w mediach, które bezpośrednio dotyczą danego kraju bądź regionu;

3) zgłaszanie miejscowej policji sytuacji, które wzbudzają podejrzenia;

4) zachowanie szczególnej czujności w miejscach, które są szczególnie narażone na ataki terrorystyczne, jak również w których przebywa wielu cudzoziemców oraz unikanie zachowań rutynowych $^{25}$.

Czyniąc centralnym punktem rozważań politykę bezpieczeństwa w kontekście zagrożenia terrorystycznego w Polsce, należy odnotować, że Polska nie jest w sposób bezpośredni zagrożona atakami terrorystycznymi. Wynika to przede wszystkim z położenia Polski w Europie Środkowo-Wschodniej, która cechuje się niewielkim zagrożeniem terrorystycznym. Mając jednak na uwadze fakt zaangażowania Polski w działania w Afganistanie, nie można zupełnie wykluczyć potencjalnego zainteresowania ze strony organizacji terrorystycznych ${ }^{26}$. Bowiem brak bezpośredniego zagrożenia nie zmienia faktu, iż ze względu na sytuację międzynarodową takie sytuacje mogą wystąpić.

\section{Zagrożenie terroryzmem w Białej Księdze Bezpieczeństwa Narodowego Rzeczypospolitej Polskiej}

Odnosząc się do bezpieczeństwa narodowego Rzeczypospolitej Polskiej w kontekście zagrożenia terrorystycznego, należy również

${ }^{25}$ Ministerstwo Spraw Zagranicznych - zagrożenia, http://www.msz.gov.pl/pl/ informacje_konsularne/informacje_dla_podrozujacych/zagrozenia/ [dostęp: 4-02-2018].

26 Ministerstwo Spraw Zagranicznych Zagrożenie terrorystyczne w Polsce i regionie, http://www.msz.gov.pl/pl/c/MOBILE/polityka_zagraniczna/polityka_bezpieczenstwa/ zwalczanie_terroryzmu_miedzynarodowego/zagrozenie_terrorystyczne_w_polsce_i_r egionie/ [dostęp: 4-02-2018 r.]. 
wskazać na znaczenie „Białej Księgi Bezpieczeństwa Narodowego Rzeczypospolitej Polskiej" z dnia 24 marca 2013 roku. Pomimo upływu czasu zdecydowana większość poruszanych w niej kwestii pozostaje aktualna. Istotne jest, że ustalając prognozy dotyczące środowiska bezpieczeństwa, zwrócono uwagę na to, iż przygotowanie do przeciwdziałania terroryzmowi będzie nie mniej wymagające niż przygotowanie do działań wojennych. Dużą wagę przywiązuje się także do cyberprzestrzeni, w której często zaznacza się aktywność ze strony terrorystów ${ }^{27}$.

Podjęcie kroków mających na celu przeciwdziałanie terroryzmowi wydaje się na tyle istotne, że również służby specjalne zostały zobligowane do podjęcia konkretnych działań. Służba Wywiadu Wojskowego otrzymała zadania polegające nie tylko na rozpoznawaniu, ale również przeciwdziałaniu ewentualnym zagrożeniom międzynarodowym terroryzmem. Podobny zakres zadań w tej dziedzinie ma również Agencja Wywiadu, która rozpoznaje i przeciwdziała zagrożeniom, które mogłyby godzić w bezpieczeństwo państwa.

W tym kontekście zagadnieniem podstawowym staje się zwalczanie terroryzmu. Na stronach Białej Księgi Bezpieczeństwa Narodowego RP podkreśla się, że jest to wyzwanie zarówno dla organów państwowych, jak i międzynarodowych, które dopiero kształtuje się na poziomie strategicznym i operacyjnym. W Polsce mamy do czynienia rozproszeniem sił i niezbędnych środków w postaci służb i instytucji powołanych do zwalczania terroryzmu. Wynika z tego pewna słabość, gdyż brak jednoznacznego określenia zadań i kompetencji podmiotów odpowiedzialnych za podejmowanie takich działań, jak również brak ich zharmonizowania skutkują pojawieniem się przeszkód we współpracy i współdziałaniu na szczeblu krajowym czy międzynarodowym ${ }^{28}$.

\footnotetext{
27 Biała Księga Bezpieczeństwa Narodowego Rzeczypospolitej Polskiej, Warszawa 2013, s. 12, http://www.spbn.gov.pl/ftp/dokumenty/Biala_Ksiega_inter_mm.pdf, [dostęp: 6-02-2018].

${ }^{28}$ Szerzej na ten temat zob.: Biała Księga Bezpieczeństwa Narodowego..., s. 64-65.
} 
Weronika Baran - Zjawisko terroryzmu a bezpieczeństwo...

Pomimo występowania nieścisłości w kwestii koordynacji działań podmiotów odpowiedzialnych za przeciwdziałanie terroryzmowi istotną rolę odgrywają instrumenty prawne, które pozwalają nie tylko na przeciwdziałanie, ale również na zwalczanie finansowania działalności terrorystycznej. W tym kontekście można wskazać nie tylko na regulacje wynikające z prawa międzynarodowego czy unijnego ${ }^{29}$, ale również na polski Kodeks karny, który zawiera wyżej przytoczoną definicję legalną przestępstwa o charakterze terrorystycznym, ustawę o przeciwdziałaniu praniu pieniędzy oraz finansowaniu terroryzmu ${ }^{30}$ oraz ustawy, które regulują kompetencje poszczególnych podmiotów powołanych $\mathrm{m}$. in. do zwalczania zagrożenia terrorystycznego.

Należy podkreślić znaczenie faktu, iż terroryzm jest zjawiskiem szczególnie groźnym zarówno dla bezpieczeństwa międzynarodowego, jak i węższym ujęciu podmiotowym - bezpieczeństwa narodowego. Ingeruje on w sposób negatywny w życie obywateli, ale także w trwałość instytucji demokratycznych i inne elementy, które nierozerwalnie wiążą się z prawidłowym funkcjonowaniem państwa. Terroryzm jest wykorzystywany jako instrument do prowadzenia radykalnej walki politycznej bądź ideologicznej i stanowi jedno z kluczowych zagrożeń wymierzonych w społeczność międzynarodową ${ }^{31}$.

W związku z powyższym szczególnie istotne wydaje się podjęcie odpowiednich działań, które przyczynią się do przeciwdziałania terroryzmowi. W Białej Księdze Bezpieczeństwa Narodowego Rzeczypospolitej Polskiej strategiczne działania podmiotów odpowiedzialnych za zapewnienie bezpieczeństwa na tym polu ujęto w sposób zbliżony do tego, które znajduje się w Strategii Bezpieczeństwa Narodowego RP. Uwypuklono m. in. takie działania, jak: „rozpoznawanie zagrożeń

${ }^{29}$ Zob. Art. 222 ust. 1 Traktatu o funkcjonowaniu Unii Europejskiej z dnia 25 marca 1957 r. (Dz. U. 2004, Nr 90, poz. 864): Unia i jej Państwa Członkowskie działaja wspólnie $w$ duchu solidarności, jeżeli jakiekolwiek Państwo Członkowskie stanie się przedmiotem ataku terrorystycznego lub ofiarq klęski żywiołowej lub katastrofy spowodowanej przez człowieka. (...).

30 Ustawa z dnia 16 listopada 2000 r. o przeciwdziałaniu praniu pieniędzy oraz finansowaniu terroryzmu (tekst jedn. Dz. U. 2017, poz. 1049 ze zm.).

31 Zob.: Biała Księga Bezpieczeństwa Narodowego..., s. 115. 
terrorystycznych dla Polski w kraju i za granicą; prowadzenie stałego monitoringu zagrożeń i opracowywanie prognoz prawdopodobieństwa zamachów na podstawie analizy ryzyka; neutralizacja zagrożeń terrorystycznych, w tym fizyczne zwalczanie terroryzmu; eliminowanie źródeł finansowania terroryzmu; ściganie karne sprawców zagrożeń terrorystycznych, zgodnie z obowiązującymi Polskę normami prawa międzynarodowego; rozpoznawanie symptomów radykalizacji zachowań i zapobieganie im; współpraca międzynarodowa na szczeblu politycznym, operacyjnym, analitycznym i prawno-karnym w obszarze zwalczania terroryzmu;"32.

W kontekście tak ujętych działań o charakterze strategicznym mających na celu zwalczanie terroryzmu nie sposób pominąć roli Centrum Antyterrorystycznego, które wraz z innymi podmiotami zapewnia ochronę antyterrorystyczną w Rzeczypospolitej Polskiej. Głównym celem funkcjonowania Centrum Antyterrorystycznego jest współdziałanie przy wymianie informacji, które umożliwi reakcję w przypadku pojawienia się jednego z czterech zdefiniowanych zagrożeń: zdarzenia terrorystycznego, które ma miejsce poza granicami Rzeczypospolitej Polskiej bądź na terytorium RP, które wpływa na bezpieczeństwo państwa i obywateli; uzyskania informacji wiążących się $\mathrm{z}$ prawdopodobnym zagrożeniem mogącym wystąpić na terenie Rzeczypospolitej Polskiej albo poza jej granicami, a także w przypadku potencjalnego finansowania działalności terrorystycznej informacji dotyczących (prania pieniędzy lub transferów środków finansowych) $)^{33}$.

\section{Podsumowanie}

Terroryzm jest na tyle nieprzewidywalnym zjawiskiem, że żadne państwa (nawet największe mocarstwa) nie są wolne od zagrożeń

32 Biała Księga Bezpieczeństwa Narodowego..., s. 171.

${ }^{33}$ Agencja bezpieczeństwa wewnętrznego - Centrum Antyterrorystyczne, https://www.abw.gov.pl/pl/zadania/zwalczanie-terroryzmu/centrum-antyterrorysty/ 62,Centrum-Antyterrorystyczne-CAT.html, [dostęp: 8-02-2018]. 
Weronika Baran - Zjawisko terroryzmu a bezpieczeństwo...

terrorystycznych. W literaturze przedmiotu podkreśla się, że również w Polsce istnieje niebezpieczeństwo nagłego, a zarazem niekontrolowanego napływu imigrantów ${ }^{34}$. Takie zjawisko może powodować trudności w zachowaniu spójności społecznej, nasilenie najistotniejszych zagrożeń, takich jak przestępczość zorganizowana czy też terroryzm, a także problem związany z tzw. migracjami nielegalnymi, w wyniku których na terytorium państwa przedostają się osoby niepożądane ${ }^{35}$.

Dodatkowo nie wszystkie kraje, które bezpośrednio sąsiadują z Polską, można uznać za cechujące się stabilnością i przewidywalnością (problematyka ta została wyeksponowana przy omawianiu bezpieczeństwa w wymiarze lokalnym, wskazano bowiem że: „Relacje Rosji z Zachodem pozostaną ważnym czynnikiem oddziałującym na bezpieczeństwo Polski, regionu i Europy. Odbudowywanie mocarstwowości Rosji kosztem jej otoczenia oraz nasilanie się jej konfrontacyjnej polityki, czego przykładem jest konflikt z Ukrainą, w tym aneksja Krymu, negatywnie rzutuje na stan bezpieczeństwa w regionie."36). Odwołując się do wcześniejszych wydarzeń, warto wskazać na koalicję Polski ze Stanami Zjednoczonymi w związku z przystąpieniem do wojny z Irakiem, która wówczas przyczyniła się do wzrostu ewentualnego zagrożenia terrorystycznego, a to z kolei mogło implikować zagrożenie dla bezpieczeństwa ze strony ogólnoświatowego terroryzmu jako wyraz sprzeciwu wobec polskiej polityki zagranicznej37.

Nie ulega wątpliwości, że nie możemy mówić o pełnym przygotowaniu ze strony Polski na wypadek ataku terrorystycznego pomimo tego, że wszyscy zdają sobie sprawę z istniejącego zagrożenia. Przyczyną tego stanu rzeczy jest przede wszystkim nieprzewidywalność

${ }^{34}$ Z. Mendrala, Polska wobec zagrożeń terrorystycznych w XXI w. Aspekty Militarne, [w:] K. Kowalczyk, W. Wróblewski (red.), Terroryzm globalne wyzwanie, Toruń 2012, s. 174.

35 R. Raczyński, Wpływ migracji międzynarodowych na bezpieczeństwo wewnętrzne państwa, „Bezpieczeństwo. Teoria i praktyka” 2015, nr 2, s. 29-30.

36 Zob. Strategia Bezpieczeństwa Narodowego..., s. 21-22.

37 Z. Mendrala, Polska wobec zagrożeń..., op. cit., s. 174. 
aktów terroru, ponieważ trudno jest wcześniej określić ewentualny czas, miejsce bądź też rozmiar zamachu. Nie możemy również przewidzieć, jakie środki zostaną wykorzystane przez terrorystów (np. broń palna, materiały wybuchowe, uprowadzony pojazd bądź statek powietrzny). Zatem niejednokrotnie wskazuje się, że walka $\mathrm{z}$ terroryzmem wiąże się z koniecznością zaangażowania licznych sił i środków 38 .

Istotnym problemem, jaki wiąże się $\mathrm{z}$ zamachami terrorystycznymi, jest fakt, że za ich pomocą terroryści oddziałują nie tylko na państwa czy organizacje międzynarodowe, ale również na całą społeczność międzynarodową. Zatem nie jest to problem poszczególnych państw i wyłącznie ewentualnego zagrożenia bezpieczeństwa wewnętrznego czy narodowego Rzeczypospolitej Polskiej, ale całej społeczności międzynarodowej. Terroryzm stanowi nie tylko realne i poważne niebezpieczeństwo dla życia i mienia poszczególnych jednostek, ale także może zagrażać porządkowi społecznemu i stosunkom międzynarodowym ${ }^{39}$.

Mając na uwadze znaczenie faktu, że zjawisko terroryzmu wpływa w sposób destrukcyjny nie tylko na państwo, ale również na społeczeństwo, władze publiczne w celu zapewnienia bezpieczeństwa swoim obywatelom muszą rozporządzać odpowiednimi służbami, które są w stanie podejmować działania adekwatne do zagrożenia. Przeciwdziałanie i zwalczanie zagrożeń terrorystycznych polega na następujących działaniach: zapobieganiu, zwalczaniu, ochronie, reagowaniu oraz prognozowaniu ${ }^{40}$.

Polska ze względu na przyjęte zobowiązania międzynarodowe jest obligowana do podejmowania działań, które mają na celu zwalczanie terroryzmu. Podobnie jak inne państwa, nie jest wolna od tego typu

\footnotetext{
38 Ibidem, s. 174-175.

${ }^{39}$ K. Liedel, P. Piasecka, Jak przetrwać $w$ dobie zagrożeń terrorystycznych. Elementy edukacji antyterrorystycznej. Warszawa 2007, s. 8.

${ }^{40}$ K. Jałoszyński, System bezpieczeństwa narodowego, [w:] K. Jałoszyński, T. Aleksandrowicz, K. Wiciak (red.), Bezpieczeństwo państwa a zagrożenie terroryzmem. Instytucje państwa wobec zagrożenia terroryzmem, Tom II, Szczytno 2016, s. 56-58.
} 
Weronika Baran - Zjawisko terroryzmu a bezpieczeństwo...

zagrożeń, dlatego też nie można lekceważyć potencjalnego niebezpieczeństwa i należy podejmować wszelkie działania, które pozwolą na maksymalne wyeliminowanie słabych stron w zwalczaniu terroryzmu i reagowaniu na to zjawisko. Wskazuje się jednak w literaturze, że: „Polska jest dla islamskich terrorystów celem zastępczym (rezerwowym), co wynika z realnego znaczenia naszego kraju na arenie międzynarodowej"41. Co istotne, nie wolno jednak w żadnym stopniu lekceważyć potencjalnych zagrożeń, gdyż ewentualny cel terrorystów byłby prawdopodobnie połączony ze spektakularnym zamachem wywołującym efekt medialny w skali światowej ${ }^{42}$.

\section{Bibliografia:}

Adamczuk M., Rodzimy terroryzm jako zjawisko zagrażające bezpieczeństwu $w$ Europie, „Bezpieczeństwo narodowe. Pozamilitarne aspekty bezpieczeństwa" 2011, nr I.

Aleksandrowicz T., Terroryzm międzynarodowy, Wyd. Oficyna Wydawnicza ŁOŚGRAF, Warszawa 2008.

Biela A., Bryk D., Kida G., Wołońciej M., Psychologiczne uwarunkowania terroryzmu jako zjawiska globalnego, [w:] P. Jaroszyński et al. (red.), Terroryzm - dawniej i dziś, Wyd. Katolickiego Uniwersytetu Lubelskiego, Lublin 2010.

Bolechów B., Terroryzm aktorzy, statyści, widownie, Wyd. Wydawnictwo Naukowe PWN, Warszawa 2010.

Jałoszyński K., System bezpieczeństwa narodowego, [w:] K. Jałoszyński, T. Aleksandrowicz, K. Wiciak (red.), Bezpieczeństwo państwa a zagrożenie terroryzmem. Instytucje państwa wobec zagrożenia terroryzmem. Tom II, Wyd. Wyższa Szkoła Policji w Szczytnie, Szczytno 2016.

Kubik T., Kossowska M., Reprezentacje poznawcze terrorysty i ich indywidualne uwarunkowania, „Psychologia Społeczna” 2007, tom 2, nr 2 (04).

Liedel K., Piasecka P., Jak przetrwać $w$ dobie zagrożeń terrorystycznych. Elementy edukacji antyterrorystycznej, Wyd. „TRIO”, Warszawa 2007.

\footnotetext{
41 T. Aleksandrowicz, Terroryzm międzynarodowy, Warszawa 2008, s. 155.

42 Ibidem, s. 154-155.
} 
Malendowicz P., Ekstremizm polityczny a bezpieczeństwo państwa i ład międzynarodowy, „Bezpieczeństwo Narodowe” 2015, nr 1.

Mendrala Z., Polska wobec zagrożeń terrorystycznych w XXI w. Aspekty Militarne, [w:] K. Kowalczyk, W. Wróblewski (red.), Terroryzm globalne wyzwanie, Wyd. Adam Marszałek, Toruń 2012.

Nowakowska-Krystman A., Zubrzycki W., Daniluk P., Mazur-Cieślik E., Terroryzm w ujęciu strategicznym, Wyd. „Difin”, Warszawa 2015.

Ochmann P., Wojas J., Współczesne znaczenie aktu wypowiedzenia wojny uwagi w kontekście konfliktu na wschodzie Ukrainy, „Bezpieczeństwo. Teoria i Praktyka" 2015, nr 3.

Szubrycht T., Cyberterroryzm jako nowa forma zagrożenia terrorystycznego, „Zeszyty Naukowe Akademii Marynarki Wojennej” 2005, nr 1 (160).

Townshend C., (tłum. R. M. Machnikowski), Terroryzm, Wyd. Uniwersytetu Łódzkiego, Łódź 2017.

Wojciechowski S., Terroryzm na początku XXI wieku. Pojęcie, istota i przyczyny zjawiska, Wyd. „CONTACT”, Poznań 2011.

Wojciechowski S., Terroryzm na poczq̨tku XXI wieku. Pojęcie przejawy przyczyny, Wyd. „CONTACT”, Poznań 2013. 